\title{
Nutritional and Bioactive Compounds Evaluation of Pleurotus pulmonarius (Freis) Quell Fruit bodies Grown on Different Wood Logs in Abia State, Nigeria
}

\section{Nwoko MC ${ }^{1}$, Onyeizu UR ${ }^{2 *}$, Okwulehie IC ${ }^{1}$ and Ukoima $\mathrm{HN}^{3}$}

${ }^{1}$ Department of Plant Science and Biotechnology, Michael Okpara University of Agriculture Umudike, Nigeria

${ }^{2}$ Department of Environmental Management and Toxicology, Michael Okpara University of Agriculture Umudike, Nigeria

${ }^{3}$ Department of Forestry and Environment, Rivers State University of Science and Technology, Port Harcourt, Nigeria

\begin{abstract}
This study was conducted to determine the nutritional and bioactive compounds composition of Pleurotus pulmonarius fruit bodies cultivated on tree logs of Dacryodes edulis, Mangifera indica and Treculia africana. Pure mycelium culture of $P$. pulmonarius was aseptically bulked in sorghum grains. Logs were cut into average length of $18 \mathrm{~cm}$ with inoculation holes of $3 \mathrm{~cm} \times 15 \mathrm{~mm}$ diameter; using High Speed Drill (HSD) of 5 drill bit and allowed to decompose for 8months. During mushroom cultivation, logs were soaked in tap water for $24 \mathrm{hrs}$ and pasteurized at $80^{\circ} \mathrm{C}$ in an improvised metallic drum (IMD) for 1hour; using cooking gas as heat source and allowed to cool overnight. $10 \mathrm{~g}$ of grain based spawn was inserted into $2 / 3$ of each hole by way of inoculation and sealed with sterile polybag for mycelium incubation. Polybags were cut open after spawn run following primordial initiation. Fruit bodies were harvested at maturity, sun-dried ground and packed in airtight container prior to further analysis. Data were analyzed using Analysis of Variance (ANOVA) and mean separation by Duncan Multiple Range Test (DMRT) while levels of significance were determined at $5 \%$. Results indicate that $P$. pulmonarius fruit bodies harvested from various tree logs were significantly different $p<0.05$ in their nutritional and bioactive compounds composition. Fruit body samples were rich in protein, carbohydrates, $\mathrm{Na}, \mathrm{K}$, and $\mathrm{Ca}$. It was also observed that fruit bodies contained significant amount of Alkaloids, Tannins and Saponins; and could be useful in drug synthesis. Therefore, adopting this technique in oyster mushroom cultivation would lead to more jobs creation and food security; but this must be done with careful regulations to avoid indiscriminate felling of trees.
\end{abstract}

Keywords: Pleurotus pulmonarius; Logs; Nutrients; Bioactive; Fruit bodies

\section{Introduction}

Mushrooms are unique biota which assemble their food by degrading enzymes and decompose the complex food materials present in the biomass where they grow [1]. Oyster mushrooms can be grown on various substrates due to its strong enzymatic features. Different substrates are used in each region depending on their availability [2]. Wheat straw, sawdust and other agricultural by-products resulting after processing of waste paper, Hazelnut and Tilia have been used in Oyster mushroom cultivation; maize, corn, rice, elephant grass, sugarcane, coffee Gume have been examined as alternative substrates for its cultivation [3-6]. These substrate materials are usually by-products from industries, households, agriculture etc, and are usually considered as wastes [7]. However, these wastes are actually resources in the wrong place at a particular time and mushroom cultivation can harness them for its own benefit [8].

Kadiri and Aizai showed that Lentinus subnudus could be cultivated on wood logs of tropical trees [9]. According to Hyunjong and Seung [10], hard woods such as poplar, willow, beech, elm and alder are the most commonly used tree species in oyster mushroom cultivation. $\mathrm{He}$ noted that unlike shiitake, Oyster mushrooms do not grow well on Oak tree logs. Hyunjong and Seung reported that since mushroom feed primarily on sapwood, any tree trunk selected for inoculation must have a larger sap wood area. The lighter or outermost wood of a log is the sapwood and the darker or inner wood is the heartwood.

The desirability of a food product does not necessarily bear any correlation to its nutritional values instead, its appearance, taste and aroma, sometimes can stimulate one's appetite [8]. Mushroom has been used as a food and medicine by different civilizations since immemorial time, due to its delicious taste and dietetic qualities [11,12]. Mushrooms are also known for their medicinal properties; they are low in calories and are ideal food for diabetic and heart patients. Mushroom has qualities like lowering the blood cholesterol level, warding against cancer and invigorating hair growth. Tewari [13] reported that the fresh mushroom contains about $85 \%$ to $90 \%$ moisture, $3 \%$ protein, $4 \%$ carbohydrates, $0.3 \%$ to $0.4 \%$ fats and $1 \%$ minerals and vitamins. Pleurotus species are good source of protein, vitamins and minerals $[8,14]$. Mushroom protein is intermediate between that of animals and vegetables, but superior to most other foods, including milk and contains all the essential amino acids required by man [15-17]. Mushrooms contain appreciable quantities of crude fibres although little information exists on the total dietary fibre (TDF) content of mushrooms. Okwulehie [18] reported high crude protein and carbohydrate contents in $P$. ostreatus cultivated on different substrates.

The world production of oyster mushroom is estimated to be 875,000 tons in 1997 [19]. China was responsible for $87 \%$ of world supply, oyster mushroom is the easiest to produce and least expensive to grow. Most of the world's supply of oyster mushrooms today comes from commercial mushroom growers. For small-scale cultivation with limited budget, oyster mushroom is the clear choice for gaining entry into the mushroom industry [12].

"Corresponding author: Onyeizu UR, Department of Environmental Management and Toxicology, Michael Okpara University of Agriculture Umudike, Nigeria, Tel: +2348065189734; E-mail: ur.onyeizu@mouau.edu.ng

Received February 25, 2017; Accepted April 25, 2017; Published April 30, 2017

Citation: Nwoko MC, Onyeizu UR, Okwulehie IC, Ukoima HN (2017) Nutritiona and Bioactive Compounds Evaluation of Pleurotus pulmonarius (Freis) Quel Fruit bodies Grown on Different Wood Logs in Abia State, Nigeria. J Pet Environ Biotechnol 7: 325. doi: 10.4172/2157-7463.1000325

Copyright: (c) 2017 Nwoko MC, et al. This is an open-access article distributed under the terms of the Creative Commons Attribution License, which permits unrestricted use, distribution, and reproduction in any medium, provided the original author and source are credited. 
This work aims to determine the nutritional and bioactive compounds composition of $P$. pulmonarius cultivated on three wood logs.

\section{Materials and Methods}

\section{Source of culture}

Pure culture of P. pulmonarius (Fries) Quel. Was obtained from the laboratory of the department of plant science and biotechnology, Michael Okpara University of Agriculture Umudike, Abia State Nigeria.

\section{Spawn production}

Spawn of $P$. pulmonarius was pruduced using sorghum grains. Grains were washed in tap water and soaked overnight. They were then boiled in water in the ratio of 1:1 (sorghum grain: water) using cooking gas for 15-20mins and drained of excess water. Completely drained sorghum grains were mixed with $4 \%(\mathrm{w} / \mathrm{w}) \mathrm{CaCO}_{3}$ and $2(\mathrm{w} / \mathrm{w}) \mathrm{CaSO}_{4}$ to optimize $\mathrm{pH}$ and prevent clumping of grains respectively as described by Muhammad [12]. Grains were later stuffed into 35cl Lucozade bottles tightly plugged with cotton wool and sterilized in an autoclave at $121^{\circ} \mathrm{C}$ for 30 mins. After sterilization, the bottles were allowed to cool, before they were inoculated with actively growing mycelium of $P$. pulmonarius by grain-to- grain transfer and incubated in the dark (at $27 \pm 2^{\circ} \mathrm{C}$ ) for 10-15 days until the grains were fully colonized by mycelium [20].

\section{Preparation of wood logs (Substrates)}

Average trees size of T. africana, M. indica and D. edulis were fell during the Hammattern season (winter) according to the recommendations of Oei. Trees were cut into logs of $18 \mathrm{~cm}$ using Electric wood saw (EWS); Model: Elect. 1710, Japan. Care was taken to ensure that the barks of the logs were not peeled off as instructed by Hyunjong [10].

\section{Inoculation holes}

Holes of depth $3 \mathrm{~cm}$ by $15 \mathrm{~mm}$ diameter were made hexagonally on each log with high speed drills (HSD) of 5 drill bit in respect to log size. Average number of holes per log was determined by the formula, according to Stamets $[21,22]$.

Where:

$$
\begin{aligned}
& \mathrm{NH}=\text { Number of holes } \\
& \mathrm{DL}=\text { Diameter of } \log (\mathrm{cm}) \\
& \mathrm{LL}=\text { Length of } \log (\mathrm{cm}) \\
& 6 \text { = Derived constant. }
\end{aligned}
$$

\section{Mushroom Cultivation}

Logs were laid in open field for 8-9 months in alternating rains and sun to allow for decomposition. Dry weight of logs $(\mathrm{g} / \mathrm{kg})$ was determined before they were soaked in water for $24 \mathrm{hrs}$. Logs were pasteurized at $80^{\circ} \mathrm{C}$ in an improvised metallic drum (IMD) for $1 \mathrm{hr}$ using cooking gas as a local heat source and allowed to cool overnight, as recommended by Canford and Nwoko [23].

Log inoculation was done by inserting about $10 \mathrm{~g}$ grain spawn of $P$. pulmonarius into $2 / 3$ of the holes and subsequently sealing the logs with transparent polybags to avoid contaminants. Mycelium recovery and colonization were clearly visible after $24 \mathrm{hrs}$; when fully colonized polythene bags were cut open to allow for fruiting [10]. Before pinhead initiation, white mycelium was visibly noticed on the cut ends of the logs. Light intensity and humidity of the air were increased to about 400 lux and $75 \%$ respectively. To achieve these, logs were watered at least morning and evening and $t$ cropping room of the mushroom house was flooded with water. Temperature was maintained at $27 \pm 2{ }^{\circ} \mathrm{C}$ $[24,25]$. Pinheads of $P$. pulmonarus were first noticed in $D$. edulis logs followed by T. africana and then $M$. indica logs after 9,10 and 12 days of inoculation respectively. Mushrooms were harvested as soon as the fruit-bodies were fully matured [7].

\section{Proximate analysis}

Proximate Analysis was carried out on each of the 3 mushroom samples. Nutrients like carbohydrates, protein, fat ash, moisture and crude fiber contents were determined by using the methods outlined in the AOAC [26]. Protein determination was carried out using the Kjedahl method. Fat determination was carried out using a Soxhlet apparatus. Also, determination of fiber content was done according to the enzymatic gravimetric method [26].

\section{Determination of minerals}

Mineral compositions of dried mushroom samples were determined by wet-ashing method. The solutions of ash obtained from the samples were dissolved in a drop of trioxonitrate $(\mathrm{V})$ acid made up to $50 \mathrm{ml}$ with deionized water and analyzed for Calcium $(\mathrm{Ca})$ and Magnesium $(\mathrm{Mg})$ using vanadate ethyldiamine-tetra acetic acid (EDTA) complexometric titration method according to MFA [27]. Sodium (Na) and Potassium $(\mathrm{K})$ were estimated using flame photometer while Phosphorus $(\mathrm{P})$ was determined using UV-visible spectrometer after making Ammonium vanado-molybdate at $436 \mathrm{~nm}$ according to the established procedures of Perkin Elmer [28].

\section{Determination of percentage bioactive compounds}

Percentage Alkaloids were determined by the methods of AOAC and Maxwell $[29,30]$. Percentage Flavonoids, Saponins and Tannins were also determined by the procedures according to Cloupai-Abyazini, Peng and Kobayashi [31], while percentage Phenols were estimated by the method of Harborn [32].

\section{Statistical analysis}

The data obtained were statistically analyzed using Analysis of Variance (ANOVA) mean separation and tests of significance were carried out by Duncan Multiple Range Test (DMRT) at $\mathrm{p}<0.05$ [33].

\section{Results and Discussion}

Results and discussion of the work on the nutritional and bioactive compounds evaluation of $P$. pulmonarius fruit bodies grown on different wood logs are presented below.

Table 1 shows the proximate composition of $P$. pulmonarius as affected by different log substrates. The results of the moisture, ash, fat, fibre, protein, carbohydrate, dry matter and free nitrogen contents of $P$. pulmonarius fruit bodies cultivated on the D. edulis, $M$. indica and T. africana are significantly different $\mathrm{p}<0.05$. This shows that the mushroom is highly nutritious when grown on these logs. This also indicates the major reason why oyster mushrooms grow naturally on already degrading logs in the wild and sometimes, around homes $[8,24]$. The relative high percentage of dry matter, carbohydrate and protein in the mushroom fruit bodies cultivated on the log substrates conforms to the work of Marlow and Ukaima [34]. The high protein contents of the $P$. pulmonarius fruit bodies cultivated on the various logs confirms the assertion by several workers that mushroom protein 


\begin{tabular}{|c|c|c|c|c|c|c|c|c|}
\hline Log Substrate & MC & ASH & Fat & Fibre & Protein & $\mathrm{CHO}$ & DM & N2 \\
\hline D. edulis & $2.63^{c}$ & $9.46^{a}$ & $2.69^{a}$ & $6.15^{c}$ & $37.17^{\mathrm{b}}$ & $41.91^{c}$ & $97.38^{a}$ & $5.95^{b}$ \\
\hline M. indica & $3.12^{\mathrm{a}}$ & $7.0^{c}$ & $2.56^{c}$ & $2.29^{a}$ & $37.86^{a}$ & $43.11^{a}$ & $96.88^{c}$ & $6.06^{a}$ \\
\hline T. africana & $2.81^{\mathrm{b}}$ & $8.48^{b}$ & $2.59^{b}$ & $6.24^{\mathrm{b}}$ & $37.68^{a}$ & $42.21^{\mathrm{b}}$ & $97.19^{b}$ & $6.03^{a}$ \\
\hline
\end{tabular}

Values are means of 3 replicates and values bearing the same letter are not significantly different $(\mathrm{P}>0.05)$. MC: Moisture content, $\mathrm{CHO}$ : Carbohydrate, DN: Dry matter

Table 1: Effect of log substrates on proximate composition (\%) of $P$. pulmonarius fruit bodies.

\begin{tabular}{|c|c|c|c|c|}
\hline Log substrate & Na & K & Mg & Ca \\
\hline D. edulis & $15.82^{\mathrm{a}}$ & $172.23^{\mathrm{a}}$ & $17.28^{\mathrm{a}}$ & $127.40^{\mathrm{a}}$ \\
\hline M. indica & $14.94^{\mathrm{b}}$ & $171.18^{\mathrm{b}}$ & $16.52^{\mathrm{c}}$ & $126.46^{\mathrm{c}}$ \\
\hline T. africana & $15.26^{\mathrm{c}}$ & $171.67^{\mathrm{c}}$ & $16.80^{\mathrm{b}}$ & $32.16^{\mathrm{c}}$ \\
\hline Values are means of 3 replicates and means bearing the same letter are not significantly different $(\mathrm{P}>0.05)$. & $32.76^{\mathrm{b}}$ & $126.79^{\mathrm{b}}$ \\
\hline
\end{tabular}

Table 2: Mineral constituents $(\mathrm{mg} / 100 \mathrm{~g})$ of $P$. pulmonarius fruit bodies as affected by different log substrates.

\begin{tabular}{|c|c|c|c|c|}
\hline Log substrate & Alkaloids. & Flavonoids. & Phenols & Tannins \\
\hline$D$. edulis & $4.07^{\mathrm{c}}$ & $0.18^{\mathrm{c}}$ & $0.94^{\mathrm{b}}$ & $1.62^{\mathrm{b}}$ \\
\hline M. indica & $4.16^{\mathrm{b}}$ & $0.21^{\mathrm{b}}$ & $0.93^{\mathrm{b}}$ & $1.52^{\mathrm{c}}$ \\
\hline T. africana & $4.34^{\mathrm{a}}$ & $0.26^{\mathrm{a}}$ & $1.05^{\mathrm{a}}$ & $2^{\mathrm{a}}$ \\
\hline Values are means of 3 replicates and means bearing the same letter are not significant at $(\mathrm{P}>0.05)$. & $2.55^{\mathrm{b}}$ \\
\hline
\end{tabular}

Table 3: Effect of wood logs on bioactive compounds composition (\%) of $P$. pulmonarius fruit bodies.

is intermediate between that of animals and vegetables, but superior to most other foods, including milk and contains all the nine essential amino acids required by man [15-17]. Low fat content of the mushroom shows that the mushroom could be good for people with cardiac problems. This is in line with the reports of Okhuoya and Okigbo $[35,36]$, who maintained that mushrooms generally contain low-oil and fat, and because of the low content of oil and fat in mushrooms, they are recommended as good supplements for patients with cardiac problems.

Table 2 represents the results of minerals compositions of $P$. pulmonarius grown on various logs. The results showed that the mushroom samples were significantly $\mathrm{p}<0.05$ rich in Sodium, Potassium, Magnesium, Calcium and Phosphorus. Potassium and Phosphorus contents were higher than other minerals analysed and also higher in mushrooms harvested from $D$. edulis logs. In this study, Sodium was found to be the lowest among other minerals analysed in the mushroom across all log substrates. The low Sodium content in mushrooms makes them ideal for persons with certain types of heart and kidney ailments [37].

The rich minerals contents in P. pulmonarius fruit bodies grown on the logs as observed in this study could be because the mushroom effectively utilized the high amount of nutrients present in the sapwood as reported by Hyunjong and Seung [10]. These mineral values are higher than those reported by Adejumo and Awosanya; Ogbo and Okhuoya, Okwulehie, Okoi and Iboh [38-40]. D. edulis gave the highest constituents of all the mineral nutrients analyzed while $M$. indica gave the lowest. The observed appreciable quantities of various mineral elements analyzed in the three mushroom samples indicates that these logs contain the corresponding nutrients in a relative amount since the nutritional composition of mushrooms depends on the substrate where they were grown [8].

Bioactive constituents of P. pulmonarius as affected by different $\log$ substrates are shown in Table 3. Results show that Alkaloids, flavonoides phenols, tannins and saponins were significantly different $p<0.05$ at different quantities. Alkaloids were found in higher quantity than other bioactive compounds analyzed. Alkaloids have powerful effect in animal physiology and are important in pharmaceutical industries for drug manufacturing [41]. Rambeli and Menini [42] reported that alkaloids are stimulants and acts by prolonging the action of several hormones. Flavonoids, phenols, tannins and saponins concentrations in P. pulmonarius fruit bodies cultivated on the different trees logs were higher than those reported by Okwulehie [38]. Flavonoids act as ant-carcinogens, anti-bactarials [43]; saponins are implicated in the prevention of parasitic fungal diseases while tannins have been used as anti-tumor agents and perform a wide range of anti-infective actions $[44,45]$. The high concentrations of these important bioactive compounds in the fruit bodies of $P$. pulmonarius with respect to their various $\log$ substrates indicate that the trees may also contain the compounds in high amount. This also shows that these mushroom samples may be considered useful in the production of certain pharmaceutical chemicals [39]. The high concentrations of these compounds may also contribute to their taste, aroma and flavor, thereby increasing their nutritional, medicinal and food value.

\section{Conclusion and Recommendations}

Pleurotus pulmonarius fruit bodies were successfully cultivated on the logs of D. edulis, M. indica and T. africana. Nutritional and bioactive compounds analysis of fruit bodies from different log substrates showed that they were rich in nutrients and could be of high pharmaceutical importance.

Therefore, efforts should be made to determine the composition of other nutrients such as vitamins and amino acids of $P$. pulmonarius with respect to the same log substrates. Commercialization of log technique of mushroom cultivation should also be encouraged since log does not easily get spent and can be repeatedly used for a long period of time. Wherever log cultivation of oyster mushroom is practiced, afforestation should be encouraged to avoid indiscriminate logging, which can lead to desertification.

\section{References}

1. Chang ST (2006A) The need for scientific validation of culinary-medicinal mushroom products. Intl J Med Mush 8: 187-195.

2. Cohen R, Persky L, Hadar Y (2002) Biotechnological applications and potential of wood degrading mushrooms of the genus Pleurotus. Applied Microbiology and Biotechnology 58: 582-594.

3. Yıldız S, Yıldız ÜC, Gezer ED, Temiz A (2002) Some lignocellulosic wastes used as raw material in cultivation of the Pleurotus ostreatus culture mushroom. Process Biochemistry 38: 301-306. 
Citation: Nwoko MC, Onyeizu UR, Okwulehie IC, Ukoima HN (2017) Nutritional and Bioactive Compounds Evaluation of Pleurotus pulmonarius (Freis) Quell Fruit bodies Grown on Different Wood Logs in Abia State, Nigeria. J Pet Environ Biotechnol 7: 325. doi: 10.4172/2157-7463.1000325

Page 4 of 4

4. Obodai M, Cleland-Okine J, Vowotor KA (2003) Comparative study on the growth and yield of Pleurotus ostreatus mushroom on different lignocellulosic by-products: Journal of Indust Microbiol Biotechnol. 30: 146-149.

5. Membrillo I, Sánchez C, Meneses M, Favela E, Loera O (2011) Particle geometry affects differentially substrate composition and enzyme profiles by Pleurotus ostreatus growing on sugar cane bagasse, Bioresource Technology 102: 1581-1586.

6. Gume B, Diriba Mulata D, Abate D (2013) Evaluation of locally available substrates for cultivation of oyster mushroom (Pleurotus ostreatus) in Jimma, Ethiopia. African Journal of Microbiology Research 7: 2228-2237.

7. Okwulehie IC, Okwujiako IA (2008) The use of local Nigerian substrates for the Pleurotus ostreatus var florida (Eger) sporophores. In: Process Production Biotech and Molecular Biology. Journal of Dynamic Biochemistry 2: 38-40.

8. Chang ST (2013) Training manual on mushroom cultivation Technology. Asian and pacific Centre for Agricultural Engineering, China pp: 24-122.

9. Kadiri JM, Aizai AH (2005) Cultivation of Lentinus subnudus (Berk) on woodlogs Bioresources Technology 94: 65-69.

10. Hyunjong K, Seung WK (2004) Log cultivation in the temperate regions. Mushworld pub. Heineart Inc. Republic of Korea. pp.140-143.

11. Agrahar-Murrugkar D, Subbulaksmi G (2005) Nutritional value of edible wild mushrooms collected from the Khashi hills of Meghalaya. Food Chemistry 89 : 599-603.

12. Muhammad AA, Muhammad S, Shabbier A, Asif HM (2007) Protein and fat contents of various Pleurotus species raised on different waste materials. Pak. J. Agric Sci. 44: 140-143.

13. Tewari RP (2008) Effect of soaking period and spawn dose on oyster mushroom production. In: Indian Mushroom M. C. Nair (ed). 2: 21.

14. Wahlid M, Satter A, Khan S (2006) Composition of wild and cultivated mushrooms of Pakistan. Mushroom in Tropics. 8: 47-51.

15. Purkayastha RP, Nayak D (2002) Analysis of protein patterns of an edible mushroom by gel- electrophoresis and its amino-acid composition. J Food Sci Tech. 18: 89-91.

16. Chang ST, Miles PG (2004) Mushroom cultivation, nutritional value, medicina effect and Environmental impact. (2ndedn), CRC p.451

17. Kurtzman RH (2009) Nutrition of Pleurotus sapidus: Effects of lipids. Mycologia 68: $268-275$

18. Okwulehie IC, Okwujiako IA, Edeoga HO (2008) Proximate, macroelement and vitamin composition of the fruit bodies of Pleurotus ostreatus (varflorida) Eger grown on different substrate and substrates supplementation. Global sci. books. 2: 184-188.

19. Chang ST (1999) World production of cultivated and medicinal mushrooms in 1997 with particular Emphasis on Lentinula edodes (Berk) Sing. China. Intl J Med Mushr 1: 291-300.

20. Shyam SP, Syed AA, Sureh MT, Mirza MV (2010) The nutritional value of Pleurotus ostreatus (Jacq: Fr) Kumm. Cultivated on different lignocellulosic agro-wastes. Yeshwant Machavidya, Nanded. pp. 431-602.

21. Stamets PS (2003) Growing Gourmet and medicinal mushrooms. Ten speed press, Berkeley, USA. pp. 554.

22. Nwoko MC (2015) Yield, heavy metals and nutritional evaluation of pleurotus ostreatus (Jacq) P. Kumm. and Pleurotus pulmonarius (Fries) Quel. Fruit bodies cultivate on three log substrates in Umudike, abia state, Nigeria. An unpublished Msc thesis of the Dept. Of plant science and Biotechnology, Michael Okpara University of Agriculture Umudike, Abia State. Nigeria. P 19.

23. Nwoko MC, Okwulehie IC, Achufusi JN (2016) Nutritional composition of
Pleurotus ostreatus (Jacq) P. kumm. Fruit bodies cultivated on deciduous tree logs in Abia State, Nigeria. International Journal of Applied Research and Technology 5: 102-108.

24. Oei $P$ (2003) Mushroom cultivation, appropriate technology for mushroom growers. Back- hughs Publishers, Leiden, The Netherlands pp.110-150.

25. Chen WA (2004) Growing shiiyale mushrooms. Mushrooms Publishers. Heineart Inc. republic of Korea: 248-260.

26. Association of Official Analytical Chemistry (AOAC) (1984) Official methods of Analysis. Intl. (17th edn) Washington D.C. pp. 266.

27. MFA (1982) Methods of food analysis. Nippon Shokuhin Kogyo Gakkaishi, Tokyo. p.40

28. Perkin-Elmer L (1982) Analytical methods for Atomic Absorption spectrometry. USA. Perkin Elmer co-operation. pp.27.

29. Association of Official Analytical Chemistry (AOAC) (1975) Official methods of Analysis (11th edn) Washington D.C. pp. 428.

30. Maxwell A, Speeris M, Pingal R, Mootoo DR, Reynolds WF (1995) Amino spirosolane steroidal alkaloids from Solanum triste. Journal of Natural Products 58: $625-628$.

31. Peng JP, Koboyashi H (1995) Nevel furastonon glycoside from Allium macrostoernum. Planta Medica 6: 58-61.

32. Harbone M (1988) Chemical test constituents and identification. John Willey and sons Ltd., New York, London, P.11-113.

33. Steel RGD, Torie JH (1980) Principle and procedures of statistics. New York: McGraw Hill Co. Inc.

34. Ukoima HN, Arikpo GE, Ikpe FN (1999) Cultural studies of mycelia of Volvariella volvacea, Pleurotus tuber- regium and Pleurotus sajor-caju on different culture media. Pakistan Journal of Nutrition 8: 1052-1054.

35. Okhuoya JA, Okogbo FO (1991) Induction of sclerotia of Pleurotus tuberregium (fr) Sing. On various farm waste product. Acad Sci 71: 1-3.

36. Okwulehie IC, Odunze IE (2004) Evaluation of the nutritional value of some tropical edible mushrooms. J. Sustainable Agri Environment 6: 157-162.

37. Quimio TH, Chang ST, Royce DJ (1990) Technical guidelines for mushroom growing in the tropics. FAO ROM, pp. 155

38. Ogbo EM, Okhuaya JA (2006) Biodegradation of aliphatic resinic and aliphatic fractions of crude oil contaminated soils by Pleurotus tuber-regium Fr. Singer a white-rot fungus. African Journal of Biotechnology 7: 4291-4297.

39. Okwulehie IC, Nwosu CP, Okoroafor CJ (2007) Pharmaceutical and nutritional prospects of two wild macrofungi found in Nig J Biotech 6: 567-572.

40. Okoi Al, Iboh $\mathrm{Cl}$ (2015) The effects of different substrates on sporophore yield, mineral and nutrient composition of Pleurotus tuberregium fries singer in Calabar. Nigeria International Journal of Agricultural Science Research 4 126-131.

41. Edeoga HO, Eriata DO (2001) Alkaloids, tanins and saponin content of some medicinal plants J. Med. Aromatic Plant Sci. 23: 344-349.

42. Rambelli A, Manini UG (2000) Manual on mushroom cultivation. FAO, Italy. Pp. 165.

43. Hilang MT, Ferraro E (1992) Phenolic compounds in food and their effects on health in Antioxidants and Cancer prevention. American Chem Society (ACS) Symposium series 507: 8-12.

44. Bidwell RSG (1979) Plant physiology. (2nd edn) Macmillan, London, pp: 643.

45. Haslam E (1996) Plant polyphenols (Vegetable Tannins) as drug possible of action. J Nat Prod 59: 205-215. 